\title{
Capacity Building for Rural Youths: Priorities for Sustainable Catfish Production in Ogun State, Nigeria
}

\author{
${ }^{1}$ Oyediran, W. O., ${ }^{2}$ Omoare, A. M., ${ }^{3}$ Sodiya C. I., ${ }^{4}$ Fakoya, E. O. \\ ${ }^{1,3,4}$ Department of Agricultural Extension and Rural Development Federal University of Agriculture, Abeokuta, \\ Ogun State \\ ${ }^{2}$ Department of Agricultural Education Federal College of Education, Abeokuta, Ogun State
}

\begin{abstract}
The study was carried out to assess the contributions of capacity building to the catfish production among the rural youth in Ogun State, Nigeria. Purposeful sampling technique was used to select 125 fish farmers for this study. Descriptive statistics and costs and returns analysis were used for the objectives while Pearson Product Moment Correlation was used to test the hypothesis. Result of the findings revealed that the mean age of the respondents was 30.08 years. All (100\%) the respondents had acceptable levels of formal education. The result indicated that majority (71.20\%) of the respondents had spent 1-4 years in catfish farming while $6.40 \%$ had been in the fishing business for more than 8 years. The mean year of fishing experience was 3.76 years. The result further showed that fingerlings selection and stocking, liming and fertilization of the pond, and group formation were the common capacity building activities undertaken in the study area. Similarly, it was found that most $(60 \%)$ of the respondents benefited from capacity building in team work improvement and knowledge sharing, increased productivity, conflict management, and input procurement. The result also showed that the respondents generated an average income of $\$ 297,850.00$ with an estimated profit of $\$ 63,110.00$ from catfish production within three months. However, catfish production were impeded by myriads of problems which include inadequate training and capacity building (76.00\%) lack of modern technologies (72.80\%), and high cost of transportation (63.20\%). There was positive and significant relationship $(p<0.05)$ between profits realized from catfish production and capacity building. It could be concluded that catfish farming was a profitable venture but were seriously affected by the lack of adequate skill and capacity building. Greater improvement in catfish production can be achieved through adequate capacity building and training for the youths in the study area.
\end{abstract}

Keywords: capacity building, rural youths, catfish production, sustainable, constraints.

\section{Introduction}

Capacity building is the ability of people, organizations and society as a whole to manage their affairs to achieve set goals. It has been asserted by Adediran, (2002) and Ugwumba, (2005) that the only way of boosting fish production and thereby move the country towards self-sufficiency in fish production is by embarking on fish farming especially catfish farming. The challenges of meeting the rapidly growing food needs of the teaming population of Nigeria cannot be successfully overcome without significant and sustained investment in research and capacity building of Nigerian youth in catfish production. Fish and fish products provide more than $60 \%$ of the total protein intakes in adults especially in the rural areas (Adekoya, 2004).

Therefore, the importance of the fishing industry to the sustainability of animal protein supply in the country cannot be over-emphasized. Regrettably, the supply of food fish has been on the decline. Currently, domestic fish production is put at 551,700 metric tonnes as against the present national demand of about 1.5 million metric tonnes estimated for 2007 (Osawe, 2007). The shortfall is said to be bridged by the importation of 680,000 metric tonnes annually amounting to about N50 billion (Odukwe, 2007). Available evidence suggests an ageing farming population in Nigeria, with an average age of 47 years and life expectancy at 47-50 years in 2008. In 2009, the national unemployment rate was 19.7 percent with the youth accounting for more than 75 percent (NBS, 2010). Increased involvement of youth in catfish farming will help to increase catfish production, reducing the problems of the ageing farm population and decreasing youth unemployment. Youths are young people in a society who are characterized by ample ideas, energy, and new ways to see life and face problems (Gobeli, 2004). Educated youths are more likely to adopt new innovations, have access to extension services and utilize agricultural loans more effectively. Youth are strong and possess abundant energy that needs proper channeling and harnessing for increased agricultural production (Ogunbameru, 2001). Youth involvement in agricultural activities will not only create career opportunities for the youths but also increase food production and to a large extent reduce the gap between food production and its demand in the community (NDE, 2003).

Three major stakeholders unequivocally exist in a rural household`s agriculture-father, mother and children, who invariably constitute the youths (Akwiwu et al., 2005). In some societies, as long as one remains a bachelor or spinster, one is a youth! These are assets for agriculture. Regardless of these huge potentials, catfish 
production has remained low in the country. This has been attributed to inadequate supplies from the local catfish farmers due to the use of poor quality catfish seeds, inadequate information, high cost of feeds, traditional techniques, small size of holdings, poor infrastructural facilities and low capital investment (Ugwumba et al., 2006). This study sees capacity building for the youth as a tool to address the constraints and decline in catfish production in the study area.

\subsection{Specific objectives}

The specific objectives are to:

i. describe the personal characteristics of catfish farmers in the study area

ii. identify the capacity building activities in the study area

iii. describe contributions of capacity building to the catfish production among the youth

iv. to estimate the profit realized from catfish production by the youth in the study area

v. identify constraints to catfish production in the study area

\subsubsection{Hypothesis}

There is no significant relationship between profit realized from catfish production and capacity building activities.

\section{Materials And Methods}

The study was carried out in Ogun State of Nigeria. The State has twenty (20) Local Government Areas with its capital at Abeokuta. Ogun Water-side Local Government Area was purposively selected. This is because of the riverine nature of the area and they are noted for artisanal activities and lacked observable evidence of serious catfish farming. Five communities were randomly selected (Iwopin, Ode-Omi, Oni, Makun, and Abigi). Simple random sampling technique was used to select 25 fish farmers from each of selected communities to make 125 respondents for this study.

\subsection{Data Collection Method}

Data collection was through primary sources using interview instruments, observations and memory recall. The instrument used for the data collection was subjected to content validity by consulting experts in the field of Agricultural Extension and Rural Development. Items found ambiguous were removed. Test-retest was carried out with twenty fishers who were not part of this study to ascertain the reliability of the instrument.

\subsection{Measurement of Variables}

Age and fishing experience were measured at interval level while sex, educational level and marital status were measured at nominal level. Constraints to catfish production were measured by the use of three alternative answers. These were extremely serious, very serious and not serious assigned 3 marks, 2 marks and 1 mark respectively.

\subsection{Data Analysis}

Simple descriptive statistics such as percentage, mean and frequency were used to analyze the objectives. Cost and returns analysis was used to estimate the gross margin and net income. In computing the net profit apart from considering the differences between the selling and purchase price, expenses incurred before the sales of fish like rent and taxes were taken into account. Gross margin is the difference between the gross income and the total variable cost.

$$
\begin{aligned}
& \text { GM = TR-TVC, Where; } \\
& \text { GM = Gross Margin } \\
& \text { TR = Total Revenue } \\
& \text { TVC = Total Variable Cost }
\end{aligned}
$$

Net Income is the difference between total revenue and total cost.

$\mathrm{NI}=\mathrm{TR}-\mathrm{TC}$ where;

$\mathrm{TC}=\mathrm{TVC}+\mathrm{TFC}$

$\mathrm{NI}=$ Net Income

$\mathrm{TC}=$ Total Cost

TFC $=$ Total Fixed Cost

Ranking in this study was used to determine the category and magnitude of each constraint over the other. Pearson Product Moment Correlation (PPMC) was used to test the hypothesis. 


\subsection{Personal characteristics of the respondents}

\section{Results And Discussion}

The result in Table 1 showed that the mean age of the respondents was 30.08 years. Most $(64.80 \%)$ of the respondents were within the age group of 30-34 years while $4.00 \%$ were above 35 years. This is indicating that most of the respondents are within the economically active population and therefore constitute a good labour force for fishery enterprise with the expectation that they would be good managers of limited available resources and can withstand rigors associated with the trade. This finding is in consonance with Theodora, (2005) who stated that people who are young are more prone to risk taking than the old, hence tends to adopt innovations. Majority $(86.40 \%)$ of the respondents were males while $13.60 \%$ were females. This revealed the dominance of male folk in catfish production while female engaged in processing and marketing of fish. All $(100 \%)$ the respondents had acceptable levels of formal education. They can read and write and solve arithmetic problems. Out of these figures $30.40 \%$ had primary school education, $56.80 \%$ had secondary school education while $20.80 \%$ had tertiary education. Most $(60.80 \%)$ of the respondents were single while $39.20 \%$ were married.

The result also indicated that majority $(71.20 \%)$ of the respondents had spent 1-4 years in catfish production while $22.00 \%$ spent $5-8$ years and $6.40 \%$ were in it for more than 8 years. The mean year of fishing experience was 3.76 years. This result indicated that the youth got into fish farming quite early in life and it is not a new enterprise to the people in the study area.

\subsection{Capacity building activities}

The result in Table 2 showed that fingerlings selection and stocking, liming and fertilization of the pond, and group formation were the common capacity building activities that were undertaken in the study area. However, marketing strategies, cropping management, space management and effective use of concrete and earthen ponds were not given much attention.

\subsection{Contributions of capacity building to catfish production}

About $60 \%$ of the respondents indicated that capacity building had helped in team work formation and knowledge sharing, increased productivity, conflict management, and input procurement while $52 \%$ of the respondents had benefited from group marketing. However, only $40 \%$ of the respondents had access to bank loans through capacity building.

\subsection{Cost and Returns of fish marketing}

Result in Table 4 showed that the estimated average cost of catfish production was $\$ 234,350.00$ in three months. The respondents generated an average income of $\$ 297,850.00$ with an estimated profit of $\$ 63,110.00$. This is an indication that catfish farming enterprise is economically viable and profitable in the study area. This result is consistent with the findings of Ugwumba and Chukwuji, 2010 who observed that fish farming is profitable in Nigeria.

\subsection{Constraints to catfish production}

The result of the findings in Table 5 showed that catfish farmers encountered many problems during the production process. These problems include inadequate training and capacity building $(76.00 \%)$ lack of modern technologies $(72.80 \%)$, and high cost of transportation $(63.20 \%)$. Other major constraints to catfish production were high cost of feed $(69.60 \%)$, lack of capital $(58.40 \%)$, scarcity of quality seeds (fingerlings) $(56.00 \%)$, and high cost of labour $(52.80 \%)$.

\subsection{Relationship between profit from catfish production and capacity building}

The result in Table 6 showed that profit generated was significant to capacity building activities at $\mathrm{p}<$ 0.05. This implies that that there is positive and significant relationship between profits realized from catfish production and capacity building. The null hypothesis is rejected and the alternate hypothesis $\left(\mathrm{H}_{1}\right)$ that, "there is significant relationship between profit generated from catfish production and capacity building activities" is therefore accepted. An increase in any of the capacity building activities, which can be interpreted as an increase in skill acquisition and competence, increases amount of earning. Hence, a respondent with more skill and experience is getting better income and profit.

\section{Conclusion}

It can be concluded that catfish farmers were economically active, experienced and operated on a small scale. The catfish farmers had undertaken capacity building activities in fingerlings selection and stocking, liming and fertilization of the pond, and group formation. Capacity building contributed to team work formation and knowledge sharing, increased productivity, conflict management, and input procurement. Catfish farming is a profitable venture. However, fish farming were hindered by myriad of problems such as, inadequate training 
and capacity building, lack of modern technologies, high cost of transportation among others. There was positive and significant relationship between profits realized from catfish production and capacity building

\section{Recommendations}

To promote the benefits of catfish production in Nigeria such as employment opportunities, source of animal protein for small income earners, reduced food insecurity and poverty alleviation it is hereby recommended that:

i. there should be introduction of systems that will ensure good standards in catfish production and marketing by extension service providers

ii. there should be provision of affordable credit facilities by financial institutions to the rural youth in the study area

iii. the rural roads should be put in good conditions to reduce transportation costs and minimize spoilage of fish.

\section{References}

[1]. Adediran, I. A. (2002). Super-Intensive Fish Culture Using Water Recirculating System. Proceedings of Seminar on Fish Farming, Success Attitude Development Centre (SADC), pp: 1-4. Lagos, Nigeria.

[2]. Adekoya, B. B. and Miller, J. W. (2004). Fish Cage Culture Potential in Nigeria-An Overview. National Cultures. Agric. Focus, 15: 10.

[3]. Akwiwu, C. D., Nwajiuba, C. U. and Nnadi, F. N. (2005). Harnessing the potentials of youths for rural household food security in Nigeria. Anim. Prod. Res. Adv., 1: 104-110.

[4]. Gobeli, V. C. (2004). Extension Rural Youth Programme: Part of a Comprehensive Strategy for Sustainable Development, in developing Countries, USDA, Washington DC

[5]. National Bureau of Statistics NBS), (2010). Unemployment profile for Nigeria 2009. www.nigeriatribuneonline.ng. Accessed on $6^{\text {th }}$ December, 2012

[6]. National Directorate of Employment (NDE) (2003). Creating more Job Opportunities. Publication of NDE, Abuja, Nigeria.

[7]. Odukwe, A., 2007. Fish Farming in the Tropics: A Functional Approach. Maxiprints, Awka, Nigeria. Book Review.

[8]. Ogunbameru, B. O. (2001). Practical Agricultural Communication. Daily Graphics (Nigeria) Limited P. O. Box, 12668 (G.P.O)

[9]. Osawe, M. (2007). Technical know-how of Catfish Grow-out for Table size in 4-6 months. Proc. Seminar on Modern Fish Farming by Dynamo Catfish Production, pp: 1-14. Lagos, Nigeria.

[10]. Theodora, O. (2005). The Role of Middlemen in Marketing of grains in Adamawa State, Nigeria

[11]. Ugwumba, C. O. A. (2005). The Economics of Homestead Concrete Fish Pond in Anambra State, Nigeria. African J. Fish. Aquacult., 4: 28-32.

[12]. Ugwumba, C. O. A. and Chukwuji, C. O. (2010). The economics of catfish production in Anambra state, Nigeria: a profit function approach. J. Agric. Soc. Sci., 6: 105-109

Table 1: Distribution of respondents according to their Personal characteristics $(n=125)$

\begin{tabular}{lll}
\hline Variables & Frequency & Percentage (\%) \\
\hline Age & 13 & 10.40 \\
$20-24$ & 26 & 20.80 \\
$25-29$ & 81 & 64.80 \\
$30-34$ & 5 & 4.00 \\
Above 35 & & \\
Sex & 108 & 86.40 \\
Male & 17 & 13.60 \\
Female & & \\
Marital status & 49 & 39.20 \\
Married & 76 & 60.80 \\
Single & & \\
Educational status & 0 & 0.00 \\
No formal education & 38 & 30.40 \\
Primary education & 71 & 56.80 \\
Secondary education & 26 & 20.80 \\
Tertiary education & & \\
Fish farming experience (yrs) & 89 & 71.20 \\
1-4 & 28 & 22.40 \\
5-8 & 8 & 6.40 \\
\hline 8
\end{tabular}

Source: Field survey, 2012 
Table 2: Distribution based on the capacity building activities $(\mathrm{n}=125)$

\begin{tabular}{llll}
\hline Activities & Always & Seldom & Not at all \\
\hline Group formation & $79(63.20)$ & $31(24.80)$ & $15(12.00)$ \\
Teaching of improved fish farming techniques & $53(42.20)$ & $28(22.40)$ & $44(35.20)$ \\
Maintenance of pond system & $61(48.80)$ & $45(36.00)$ & $19(15.20)$ \\
Liming and fertilization of pond & $82(65.60)$ & $43(34.40)$ & $0(0.00)$ \\
Fingerlings selection and stocking & $95(76.00)$ & $30(24.00)$ & $0(0.00)$ \\
Feed selection and formulation & $75(60.00)$ & $41(32.80)$ & $9(7.20)$ \\
Effective use of concrete and earthen ponds & $40(32.00)$ & $34(27.20)$ & $51(40.80)$ \\
Space management & $47(37.60)$ & $15(12.00)$ & $63(50.40)$ \\
Cropping management & $55(44.00)$ & $34(27.20)$ & $36(28.80)$ \\
Marketing strategies & $42(33.60)$ & $24(19.20)$ & $59(47.20)$ \\
\hline
\end{tabular}

Source: Field survey, 2012

The values in parenthesis are percentages.

Table 3: Contributions of capacity building to catfish production $(n=125)$

\begin{tabular}{lll}
\hline Contributions & Frequency & Percentage \\
\hline Team work improvement and knowledge sharing & 87 & $69.60^{*}$ \\
Facilitation of direct input procurement & 72 & 57.60 \\
Increased productivity & 78 & $62.40^{*}$ \\
Ease and group marketing & 65 & 52.00 \\
Ease of access to loan from banks & 50 & 40.00 \\
Conflict management and resolution & 75 & $60.00^{*}$ \\
\hline
\end{tabular}

Source: Field survey, 2012

*Multiple responses

Table 4: Costs and returns for catfish production $(n=125)$

\begin{tabular}{ll}
\hline Items & Values (A) \\
\hline Total Revenue (TR) @ $350 / k g$ & $\mathbf{2 9 7 , 8 5 0 . 0 0}$ \\
Variable Cost (VC): & $18,000.00$ \\
Catfish seeds @20/fingerling & $109,650.00$ \\
Catfish feeds & $34,700.00$ \\
Labour & $3,500.00$ \\
Fuel & $5,250.00$ \\
Water/electricity & $23,800.00$ \\
Transportation & $16,450.00$ \\
Miscellaneous & $\mathbf{2 1 1 , 3 5 0 . 0 0}$ \\
Total Variable Cost (TVC) & \\
Fixed Cost: & $2,090.00$ \\
Taxes & $21,000.00$ \\
Rent & $\mathbf{2 3 , 0 9 0 . 0 0}$ \\
Total Fixed Cost (TFC) & $\mathbf{8 6 , 5 0 0 . 0 0}$ \\
GM (TR-TVC) & $\mathbf{6 3 , 1 1 0 . 0 0}$ \\
NFI(GM-TFC) & \\
\hline
\end{tabular}

Source: Field Survey, 2012

Table 5: Constraints to catfish production $(n=125)$

\begin{tabular}{llll}
\hline Constraints & ES & MS & NS \\
\hline Inadequate training and capacity building & $95(76.00)$ & $26(20.80)$ & $4(3.20)$ \\
High cost of feed & $87(69.60)$ & $21(16.80)$ & $17(13.60)$ \\
Lack of capital & $73(58.40)$ & $32(25.60)$ & $20(16.00)$ \\
Scarcity of seeds & $70(56.00)$ & $40(32.00)$ & $15(12.00)$ \\
Lack of modern technologies & $91(72.80)$ & $24(19.20)$ & $10(8.00)$ \\
High cost of transportation & $79(63.20)$ & $27(21.60)$ & $19(15.20)$ \\
High cost of labour & $66(52.80)$ & $41(32.80)$ & $18(14.40)$ \\
Lack of land & $57(45.60)$ & $43(34.40)$ & $25(20.00)$ \\
Poaching & $46(36.80)$ & $67(53.60)$ & $12(9.60)$ \\
Inadequate water supply & $45(36.00)$ & $66(52.80)$ & $14(11.20)$ \\
Mortality of fish & $59(47.20)$ & $51(40.80)$ & $15(12.00)$ \\
Poor storage facilities & $61(48.80)$ & $34(27.20)$ & $29(23.20)$ \\
\hline
\end{tabular}

Source: Field Survey, 2012 ES = Extremely Serious, MS = Moderately Serious, NS=Not Serious The values in parenthesis are percentages.

Table 6: Relationship between profit from catfish production and capacity building

\begin{tabular}{llll}
\hline Variable & r & p-value & Decision \\
\hline Profit & 0.75 & 0.04 & $\mathrm{~S}$ \\
\hline
\end{tabular}

Source: Field Survey, 2012

$\mathrm{S}=$ Significant at $\mathrm{p}<0.05$ level 